\title{
Amizade e Biopolítica: um passeio pelas modulações do capital
}

\section{Friendship and Biopolitics: a ride on the capital modulations}

CAIO AUGUSTO RAMOS DE CASTILHO
Universidade Federal Fluminense

CLARA SYM CARDOSO DE SOUZA COSTA Universidade Federal Fluminense

ANA CAROLINA DIAS RAMOS Universidade Federal Fluminense

$$
\text { JÚLIA PAIM MAS }
$$

Universidade Federal Fluminense

VINÍCIUS JERÔNIMO DA SILVA Universidade Federal Fluminense

DIOGO DE LIMA MUNIZ BARROSO Universidade Federal Fluminense

MARCELLE DA SILVA FREITAS Universidade Federal Fluminense

RAFAEL PIRES PINTO Universidade Federal Fluminense

TALI FIRER Universidade Federal Fluminense JÚLIA VIRGINIO CÂMARA Universidade Federal Fluminense

JIULIA CALIMAN MUYLAERT DE MENEZES Universidade Federal Fluminense

DANICHI HAUSEN MIZOGUCHI Universidade Federal Fluminense 
Resumo: O presente artigo trata de problematizar um dos aspectos microfísicos da atualidade: o jogo biopolítico das amizades. Amparado no conceito foucaultiano de poder e na especulação deleuzeana acerca da sociedade de controle, coloca um estranho bando a circular no socius, sendo alcançado por discursos verdadeiros os quais modulam a amizade no presente. Fazendo uso de imagens nas quais enunciações acerca da amizade ensejam uma conexão entre saúde, capital e amizade, persegue um estranhamento em relação àquilo que somos e que ajudamos a fazer de nós mesmos. Tal imagética, todavia, não se presta a definir contornos, mas a apostar que outros mundos são possíveis.

Palavras-chave: Amizade. Biopolítica. Capitalismo.

\begin{abstract}
The current paper intends to inquire about one of the microphysical aspects of the present: the biopolitical game of friendship. Supported by the foucaultian concept of power and the deleuzian speculation about the societies of control it sets in motion a strange gang/group in the socius, the group is reached by scientific discourses of truth which modulates friendships in the present. By utilizing images where enunciations about friendships agglutinates a connection between health, capital and friendship, it is elicited an estrangement in relation of what we are and what we help ourselves to become. This imagery, however, does not intend to define rigid forms, but to indicate that other worlds are possible.
\end{abstract}

Keywords: Friendship. Biopolitics. Capitalism. 
Chegaram à praça: mesmo não sendo muitos, eram uma pequena multidão. Cabia-lhes a invenção concomitante de um problema e de um modo de andar. Era a aposta simultaneamente de andança e de pesquisa - na criação de um nós que não caísse na indecência de falar em nome de outros (Foucault, 1979), mas que se desse a estranhar o que há e apostar em outras modulações do mundo. Tratava-se, pois, da criação de um coletivo necessariamente tomado em um jogo verbal, temporal e espacial marcado pela pluralidade dos que falam. Um bando, enfim, modulado no estranhamento acerca de uma certa micropolítica. Eis a pergunta que disparava o movimento: o que os jogos do presente faziam das relações de amizade?

Restava, pois, andar e estranhar.

$$
* * * *
$$

Dar início à andança com a bagagem de frágeis verdades ${ }^{1}$, mas como se enxergasse 0 mundo pela primeira vez: bando noviço, bando curioso, bando tenso. Se era a política da amizade que the interessava - mais do que tudo, que lhe dava condições de existir -, nada mais profícuo do que habitar a superfície do socius - já que era nela, materialmente, que os jogos de invenção do presente se davam. Lembravam e apostavam na especulação feita por Deleuze anos antes: "sociedades disciplinares era o que já não éramos mais, o que deixávamos

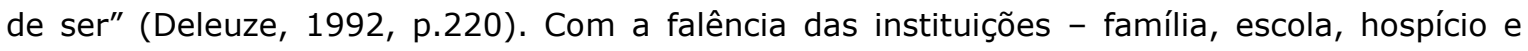
tantas outras - o poder agora se disseminava e se espraiava a céu aberto. Sociedade de controle: poder na rua, poder high-tech. O poder, definido por Foucault como algo que "opera sobre o campo de possibilidade onde se inscreve o comportamento dos sujeitos ativos; ele incita, induz, desvia, facilita ou torna mais difícil, amplia ou limita, torna mais ou menos provável" (1995, p.243) já circulava em imagens leves e flexíveis. Poder eminentemente relacional - o qual talvez, em certo momento, tenha tomado parte em um estranho jogo de amizades: era atrás disso que o bando ia.

Mas não se tratava de qualquer andar - ou, por outra, de qualquer habitação da rua. Havia uma aposta metodológica - uma aposta em certo estilo de produção de conhecimento. Uma aposta que reafirmava a potencialidade dos espaços frente à fixidez dos lugares, desfazendoos. Operar o espaço como produto de inter-relações, sendo dessa forma, possibilidade de multiplicidade, e como tal é necessariamente fruto de práticas materiais, políticas, a serem efetivadas, portanto nunca finalizado, sempre como devir (Massey, 2008). Enquanto pedestres, queriam transformar a rua, geometricamente definida por um urbanismo, em espaço (Certeau, 2012) onde um outro mundo pudesse se abrir. Era, pois, de um andar cínico que se tratava: "Não é para evangelizar que eles caminham, e sim para provocar, inquietar" (Gros, 2010, p.133).

1 "Convém assinalar aqui que estes discursos verdadeiros de que precisamos só concernem àquilo que somos em nossa relação com o mundo, em nosso lugar na ordem da natureza, em nossa dependência ou independência quanto aos acontecimentos que se produzem. Não são, de forma alguma, uma decifração de nossos pensamentos, de nossas representações, de nossos desejos" (GROS, 2006, p.606). 
Perder-se na cidade - e fazê-lo com instrução, como quem o faz em uma floresta (Benjamin, 1987). Nela, catar pequenas falas - falas ordinárias, falas do dia-a-dia, falas subjetivantes. Performatizar um hiperativismo pessimista: tudo é perigoso - e se tudo é perigoso, sempre haverá algo a ser feito (Foucault, 1995a). Uma peripatética, enfim: estranhar o mundo, estranhar as amizades moduladas no presente.

Era assim que, em um movimento estranho, operado como quem não acredita nos começos ou nos fins e se vê sempre em meio (Deleuze e Guattari, 1995), o bando - desde sempre na rua - ouvia afirmações as quais começavam a lecionar acerca da amizade. Entre barulho de ônibus, marulho, choques de ordem e galhofas, algumas falas tocavam com força os ouvidos atentos. Em uma esquina, os ruídos das máquinas passantes lhes chegavam aos ouvidos e o vento gelado era absorvido pelos poros. Na esquina seguinte uma voz falava mais alto que o som dos motores: "pessoas muito solitárias ao longo da vida tendem a ser mais indefesas, ter noites ruins de sono e sofrer mais com as complicações enfrentadas ao longo da vida - como, por exemplo, o estresse" (Gonçalves, 2011). Não parecia se tratar de uma fala qualquer: era a fala de um especialista, um estranho cientista de praça pública, o qual acreditava enunciar de modo neutro uma verdade acerca do tema. Os participantes do bando sabiam - carregavam a bagagem de frágeis verdades - que a categoria dos enunciados havia sido importante em um primeiro movimento intelectual feito por Michel Foucault - aquele momento da obra em que se dedicara a engendrar arqueologias do saber. Em um jogo no qual eram partícipes uma certa política do olhar e do falar, os enunciados - ou seja, "uma proposição ou frase considerada desde o ponto de vista de suas condições de existência, não como proposição ou frase" (Castro, 2009, p.136) - efetivavam uma modulação superficial da verdade. Em outros termos, a positividade de um discurso o qual construía uma política de saber e, com ela, construía o mundo: um inusitado disparate entre coisas e palavras, uma estranha junção entre o dito e o visto. Talvez naquele mundo em que o bando se perdia, as amizades merecessem ser objetos de verdade. Mas como? E para quê?

$* * * *$

O bando andava: habitava a cidade, sentia seus cheiros, suas cores, suas dores e suas delícias. A brisa do mar, o calor do concreto, o grito dos mercadores, a inquietação dos universitários: era tudo uma cidade. Era nela que os enunciados circulavam - fluíam, sumiam, reapareciam. Andar na cidade com essa proposta em mente, quase um desafio, era reinventar um caminhar, antes quase desapercebido do mundo à volta, era criar novas formas de ocupar esse espaço. O bando apurava os sentidos e se punha a ouvir e ver a cidade não com olhos à frente, mas, em grupo, com olhos à volta, talvez se pudesse dizer, com olhos nos pés, atentos às passadas. Não à toa, a fala que ouviam era precisa: de acordo com o cientista - ele seguia falando - havia uma relação diretamente proporcional entre a solidão e o risco de alguém 
padecer do mal de Alzheimer (Gonçalves, 2011). O bando, tão novato quanto inquieto, estranhava aquela relação enunciativa: o que ofertava condições de possibilidade a que a amizade, a solidão e a saúde aparecessem amarradas em uma mesma discursividade? Que mundo tal amarra ajudava a construir? Seria esse um dispositivo daquele jogo que o bando intuía ser o que Michel Foucault certa vez chamara de biopolítica? Poderia, afinal, a amizade fazer parte deste jogo? E que implicações tal desmerecimento da solidão teria em relação ao modo como as amizades eram destinadas a se montar naquele mundo em que começavam a errar?

Com mais perguntas do que respostas, o que restava ao bando eram as pernas e o chão da cidade - e, sobretudo, a atenção aos enunciados que se dirigiam às relações de amizade.

$$
\text { **** }
$$

O bando, pois, andava. Os passos eram tateantes, a atenção era constante, as certezas eram poucas. A lembrança do que Deleuze chamara, tempos antes, de sociedade de controle, remetia os olhos e ouvidos aos enunciados e imagens que circulavam nos aparatos midiáticos leves, fluídos, quase um gás. O bando apercebia-se que grandes figuras de um telejornal famoso também tinham suas ponderações a fazer acerca da solidão: "aquelas pessoas que passam grande parte da sua vida sem interações sociais têm prejuízos relacionados à longevidade que podem ser comparados a fumar cigarros todos os dias, ser alcoólatra ou obeso. É cientificamente comprovado que o isolamento social aumenta em cerca de 30\% o risco de morrer mais cedo" (Gonçalves, 2011). Que força subjetivante tal fala carregaria consigo? Afinal, que mundo - o mundo do bando - ajudava a construir?

O jornal televisivo evidentemente não estava sozinho - e não produzia enunciados sozinho. Um médico, em entrevista a um jornal impresso, dizia que "evitar a proximidade e os vínculos pode ter influências negativas sobre o sistema imunológico, principalmente para idosos" (Jetten et. al., 2010, p.37), e que "pessoas menos sociáveis tem duas vezes mais risco de contrair resfriado, em comparação com aqueles que travam contato com mais pessoas" (idem, ibidem, p.38).

Do jeito que esses enunciados rapidamente proliferavam, o bando não mais se surpreenderia se, ao lado das advertências sobre os malefícios do cigarro, espalhadas pela cidade, houvesse placas alertando sobre o grande perigo de se estar só. Beber ou comer sozinho, então, pareciam abalar irreversivelmente a longevidade. O bando, já um tanto quanto irônico, se perguntava: será que a solidão em breve passaria à ilegalidade?

Quanto mais se punham a andar, atentos com a política da amizade, mais lhes chamavam a atenção falas de especialistas que capturavam em suas construções biologizantes e saudáveis de mundo as amizades. Seria esse um indício daquilo que Nikolas Rose e Paul Rabinow (2006) haviam chamado de século biológico, de "tentativas mais ou menos racionalizadas de intervir 
sobre as características vitais da existência humana" (idem, ibidem, p.28), cujo "campo contestado de problemas e estratégias está mais crucial e enigmático do que nunca" (idem, ibidem, p.28)? Seriam, por fim, indícios sub-reptícios de uma atualização daquilo que Michel Foucault chamara de biopolítica?

Se a biopolítica dizia respeito, dentre outras coisas, à passagem de um sistema o qual deixava viver e fazia morrer a outro o qual fazia viver e deixava morrer (Foucault, 1988), outros elementos eram necessariamente trazidos à baila. Na leitura de Rose e Rabinow, 0 bando entendia que a biopolítica dizia respeito a "um ou mais discursos de verdade sobre o caráter 'vital' dos seres humanos, e um conjunto de autoridades consideradas competentes para falar aquela verdade" (2006, p.29), a "estratégias de intervenção sobre a existência coletiva em nome da vida e da morte, inicialmente endereçadas a populações que poderiam ou não ser territorializadas em termos de nação, sociedade ou comunidades pré-dadas" (idem, ibidem, p.29) e, por fim,

a modos de subjetivação, através dos quais os indivíduos são levados a atuar sobre si próprios, sob certas formas de autoridade, em relação a discursos de verdade, por meio de práticas do self, em nome de sua própria vida ou saúde, de sua família ou de alguma outra coletividade, ou inclusive em nome da vida ou saúde da população como um todo (idem, ibidem, p.29).

Era a amizade, era a biopolítica, era um jogo de poder estranhado e interrogado por um bando que vagava na cidade à cata de enunciados.

$* * * *$

Sob os passos tortuosos e os ouvidos atentos, a palavra agora estava com a dupla formada por um médico e um psicólogo que, como em um show à rua, entoavam que mais de 350 milhões de pessoas de todas as idades sofrem de depressão (WHO, 2012) - e não demorou muito para que os especialistas relacionassem diretamente a doença à amizade: "Há um remédio preventivo contra a depressão que não custa nada e nem tem contraindicação. Viver rodeado de amigos é uma das melhores receitas para nunca chegar perto de um dos principais males da vida moderna" (ABP, 2006). O bando ouvia a amizade sendo colocada como antídoto, um medicamento o qual objetivava dar suporte e segurança aos indivíduos. Um pouco de soslaio, a lembrança de que tampouco a arte escapa desse tipo de enunciado - já dizia um grande compositor da música popular brasileira: é impossível ser feliz sozinho (Jobim, 1967) desdobrava os questionamentos.

Com tantos exemplos dispersos e, ao mesmo tempo, ironicamente conectados, notava-se como a amizade - e a contrapelo também a solidão - estava sendo constantemente construída próxima ao campo das patologias - ou, no limite, vinculada ao campo da saúde. O bando perguntava-se: a serviço de que estavam tais amizades? Era inevitável pensar que essa construção patológica da solidão se vinculava diretamente com o mundo capitalista em que o 
bando se sabia inserido. Menos interações sociais seriam sinônimo de menos consumo? Será por isso que a solidão era tão temida?

O bando estranhava as verdades que naquele território circulavam: tais verdades operavam, tais verdades produziam o mundo. De fato, todos aqueles enunciados radicalmente concretizavam forças, e, portanto, criavam e conduziam uma série de existências e subjetividades. Definições específicas à tradição da philia grega, que garantam disponibilidade integral, interesses compartilhados, semelhanças intelectuais, alegria, segurança e, dentre tantas outras obrigações morais, agora também engendravam bem-estar e saúde.

\section{$* * * *$}

O bando andava, mas não se furtava à leitura. Para além de qualquer erudição de almanaque ou de gabinete, tal movimento dava-se a montar aquilo que os gregos chamavam de paraskeué: "uma preparação ao mesmo tempo aberta e finalizada do indivíduo para os acontecimentos da vida" (Foucault, 2006, p.387). Era assim que se instrumentalizavam e modulavam o mundo com o qual se encontravam. Se entendiam, pois, sob aquilo que certa feita Michel Foucault chamou de epistéme moderna: aquele modo de saber que inventa o ser humano como objeto de conhecimento científico - e, consequentemente, de intervenção. A referência não era qualquer, dizia respeito àquilo que Foucault, em As palavras e as coisas (2000), chamara de a invenção do homem - um campo discursivo no qual o ser humano passava a ser simultaneamente sujeito e objeto do conhecimento.

O bando começava a supor que a religião do capital, "essencialmente a serviço da resolução das mesmas preocupações, aflições e inquietações a que outrora as assim chamadas religiões quiseram oferecer resposta" (Benjamin, 2013, p.21), tem como uma de suas engrenagens principais a operatividade da ciência. Acompanhando o jogo capitalístico da produtividade, diversas pesquisas científicas pipocavam na tentativa de empreender um mundo melhor. O bando não se furtava a relembrar das raízes históricas do par ciência-capital - uma gênese a qual, em última instância, poderia ser chamada de moderna.

A cada passo íamos aprendendo a observar o mundo de modo menos dócil. As campanhas da Amizade Premiada nas academias de ginástica, cursos de inglês e instituições de ensino privadas agora tomavam um caráter quase assustador. Essas campanhas ofereciam desconto a todos que trouxessem algum amigo para se tornar membro da instituição. Trazer um amigo para o curso de inglês ou para a graduação poderia render viagens, tablets e as mais variadas formas de recompensa. Também, nos templos do culto ao corpo perfeito, o investimento financeiro e emocional na normatização se associava à visão utilitarista da amizade. Num ethos de 'cada um por si' as amizades pareciam ser definidas pelo benefício que poderiam trazer ao indivíduo, como falava o sábio microfonado no meio do passeio público: "Quando uma pessoa se torna obesa, seus amigos têm 45\% mais risco de engordar" (O Globo, 2010, p.52). As 
pesquisas pareciam indicar à geração saúde os amigos normatizados, já que acabariam dando aquela força na conquista do corpo ideal. Quantidade parecia ser um fator importante, mais amigos, mais saúde, mais músculos, mais amores, mais descontos, mais consumo, mais eu. Um mundo o qual

\begin{abstract}
concebe a subjetividade como produção, e considera que uma das principais características dessa produção nas sociedades 'capitalísticas' seria, precisamente, a tendência a bloquear processos de singularização e instaurar processos de individualização. Os homens, reduzidos a condição de suporte de valor, assistem, atônitos, ao desmanchamento de seus modos de vida. Passam então a se organizar segundo padrões universais, que os serializam e os individualizam. Esvazia-se o caráter processual (para não dizer vital) de suas existências: pouco a pouco, eles vão se insensibilizando. A experiência deixa de funcionar como referência para a criação de modos de organização do cotidiano: interrompem-se os processos. de singularização. Portanto, é num só movimento que nascem os indivíduos e morrem os potenciais de singularização. Tudo isso constitui uma imensa fábrica de subjetividade, que funciona como indústria de base de nossas sociedades (Guattari e Rolnik, 1996, p.38).
\end{abstract}

O andar pelas avenidas revelava nas lojas de eletrodomésticos promoções similares: aqueles que comprassem uma TV e levassem um amigo para também arrebatar uma nova tela grande obteriam descontos na compra. Ironicamente a loja propagava a ideia de que a amizade não tem preço enquanto, paradoxalmente, apontava para o valor monetário da relação virtuosa. Assim como as velhas promoções de pague três e leve quarto, a amizade agora parecia estar envolvida no jogo da rentabilidade. Mas quando foi que a amizade se tornou algo tão obviamente rentável? A caminhada só levantava questões, pois, naquelas promoções, ter um amigo significava economia, e de maneira bem matemática, quanto mais amigos, mais descontos. A capitalização da amizade começava a ser percebida de maneira mais concreta.

$* * * *$

Passeando pela orla, assistíamos o sol se pôr. Os questionamentos continuavam a borbulhar. Entre conversas e risadas, uma voz sobressaia. Alguém pregava uma fé com muita voracidade e seu discurso atraia citadinos que iam se aglomerando ao redor: "seus amigos mal devem imaginar, mas a presença deles melhora em 50\% a chance de você viver mais" (Gonçalves, 2011). Enquanto uns ouviam suas palavras com admiração, outros as ouviam com certo frenesi. Pela cidade os dizeres dos especialistas iam lecionando o que é melhor para todos, quais comportamentos são adequados e quais não são, lembrando sempre os benefícios de sermos saudáveis. Inquietos com isso, a resignação não era uma opção: as dúvidas iam se acumulando.

Os poucos carros vistos lembravam que a noite chegara. Atravessada a rua, ocupamos as duas únicas mesas do pé sujo da esquina. Condensados pelas dúvidas acerca das verdades enunciadas, algo naquele momento pareceu nos envolver ainda mais: o não muito grande aparelho televisor do bar. Citando os escritos de uma revista, o jornalista dizia: "o convívio em 
vários círculos sociais torna as pessoas mais felizes, saudáveis e ajuda a viver mais; além de proporcionar trocas afetivas e intelectuais, o hábito funciona como vacina para fortalecer a saúde física e mental - e ainda costuma ser bastante divertido" (Jetten et. al., 2010, p.37). De um instante para outro, os rostos focavam-se na televisão. $O$ discurso transmitido se intrometia em muitas vidas: era mais um sábio que compartilhava seu conhecimento. Em apenas uma frase, noticiava algo que poderia tornar a todos saudáveis e felizes, e isso era dito de forma tão definitiva e certeira: bastava ampliar o convívio nos círculos sociais. Dentre as tantas incertezas do bando, algo parecia estar certo, nesse jogo da ciência - da epistéme moderna e do capital a amizade tinha sido capturada.

A inquietude e as inúmeras garrafas sobre a mesa aceleraram o ritmo da bebedeira e a amizade tornava-se presente nas conversas do bar. Com os smartphones em mãos, um conferia o Facebook, outro postava uma foto no Instagram. Tinha aquela que estava falando no celular e aquele que pedia a opinião dos amigos sobre um gatinho do Tinder. De repente, compartilhava-se um estudo que aparecera em um destes dispositivos e na mesa lia-se: "cada amigo triste coloca o confrade sete por cento mais para baixo (...) a felicidade é muito mais potente: ter um amigo contente aumenta a chance de ficar feliz em mais de quinze por cento e, a partir dele, cada pessoa alegre contribui com mais dez por cento" (idem, ibidem, p.37).

O estranhamento em relação às amizades só aumentava, assim como as garrafas de cerveja sobre a mesa. A imprevisibilidade da vida se contrapunha à precisão desses cálculos; tão exatos, apontavam que nos casos de tristeza é só apostar nos amigos, pois eles potencializariam a felicidade. Eram muitos os enunciados em que os cientistas se punham na tarefa de comprovar as vantagens de se ter amigos, e em como a amizade interpelava as práticas de intervenções sobre a vida, fazendo um apelo à saúde e à felicidade. Já com os bolsos esvaziados, fechamos a conta e partimos.

Ficava cada vez mais claro que os ditos sábios cientistas eram produtores de um saber regulador. Os discursos de verdades que participavam do jogo de saber-poder se mostravam com estratégias específicas que operam de acordo com a lógica da vitalidade. Atravessando os modos de existência, essas estratégias pareciam eficazes, produzindo modos de subjetivação que levam os indivíduos a atuarem sobre si próprios. Lembrando de Foucault, perguntávamonos se a amizade não estaria sendo convocada pela biopolítica para participar do jogo que nos quer saudáveis - e, logo, produtivos.

$* * * *$

Andando nas ruas percebemos nas bancas de jornal, e quase em cada esquina, entonações de verdades sendo consumidas. Nas revistas expostas, a amizade estava estampada na capa ao lado de receitas culinárias para uma vida saudável, lições sobre sexo e exercícios para uma boa forma: "Amizade, por que é impossível ser feliz sozinho" (Super Interessante, 2011). Sentados à orla para a leitura da brochura, percebíamos os ditos sérios ali descritos como vozes a se propagar por aquele movimentado litoral. Cabeças pareciam saltar das páginas para 
fazerem ouvir as últimas notícias do mundo da saúde: tal qual uma dose diária de vitamina $\mathrm{C}$ ou de equinácia, a amizade pode fazer com que o corpo fique mais imune a problemas de saúde e, portanto, mais apto ao trabalho. Virando as páginas, novas cabeças pululavam expondo os últimos achados das pesquisas americanas, contando-nos que "o fator que mais influi no nível de saúde das pessoas não é o dinheiro, os genes, os elementos da rotina ou a alimentação, mas os amigos" (idem, ibidem). Extrapolando o bem-estar, os ditos da revista pareciam nos convocar novamente a estar saudáveis, atendendo ao jogo biopolítico que ia amarrando amigos à saúde quase como remédios.

Podia-se imaginar, em um futuro não muito distante, um médico em um check-up perguntando não só sobre o histórico de saúde pessoal e familiar do paciente, após medir a pressão sanguínea, usar o estetoscópio para averiguar os batimentos cardíacos, indagar sobre os hábitos de dieta, averiguar o padrão de exercícios físicos e receitar exames, acabasse por questionar acerca de tópicos até então pouco comuns em uma consulta médica. Ele talvez emendasse uma série de questões com o prontuário de anamnese em mãos: quantos amigos você tem? Qual a importância deles em sua vida? Costuma passar momentos agradáveis com eles? A quais grupos sociais você pertence? Qual a diversidade deles? O médico talvez parabenizasse o paciente pelas interações saudáveis que vem cultivando - o qual sairia do consultório sabendo que, como pertence a tantos grupos, não tem necessidade de se preocupar caso negligencie a atividade física ou a dieta saudável uma vez ou outra. O médico, com a calculadora em mãos, talvez avisasse que o paciente poderia acrescentar mais uma porção de batatas fritas caso também agregasse mais três bons amigos em seu círculo social. Às gargalhadas, o bando mergulhava no inusitado devaneio imaginando velhinhos que conversavam na praça dizendo-se felizes por finalmente se encontrarem, já que a taxa de colesterol de ambos vinha fora de controle; sob os bons resultados de um próximo exame eles talvez decidissem que não era mais necessário passarem a tarde juntos - a não ser que quisessem adquirir uma televisão de plasma de última geração.

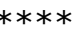

Sentados à mesa de um restaurante qualquer, entre os frascos de molho de soja, palitos de dente e sachês de um pó branco e refinado, nos deparamos estranhando as embalagens antes tão familiares. Frases que outrora passaram como brincadeiras diárias, agora, pelos vários pares de olhos que constituem o bando, tomam outros significados e fazem surgir novos estranhamentos. O pó refinado em cima da mesa fala diretamente para todos nós: sorria mais, descansar demais leva a oxidar-se, encontre novas fronteiras, reconheça seu valor, e a frase mais interessante de todas: faça mais amigos. Que força convoca os publicitários a criar essa união açucarada? Estariam eles preocupados com a captura de um estilo de vida específico, feliz e saudável, ou seriam apenas desavisados caçadores em busca de lucro? Será que, de fato, saúde, alegria, amizades, produtos e dinheiro se conectam? 
No banco da praça fomos interpelados por um empertigado senhor - economista, dizia ele. Em seu terno bem cortado e nos mostrando sua credencial, queria nos contar a novidade: "as pessoas sentem-se mais felizes em duas situações, quando recebem um aumento ou quando fazem mais amigos". O entreolhar confuso do bando não lhe parou: ganhar um amigo, inclusive, dizia ele, "equivale a receber R\$134 mil a mais de salário anual" (O Globo, 2010, p.52-53) O choque dos nossos olhares não incomodou o homem, que já se dirigia ao próximo grupo para espalhar a informação. Acabávamos de nos deparar com questões que já haviam nos atravessado, mas talvez nunca com a contundência daquele encontro: sob a capitalização das relações, a amizade praticamente materializada em dinheiro.

Ia ficando difícil não notar, em nossos passeios pelas ruas, a amizade transformada em moeda de troca. Em um mundo capitalizado, que tem ciclos gestacionais cada vez mais estreitos para o lucro, não era de se estranhar a amizade ganhando um espaço definido no calendário das negociatas, afinal, datas comemorativas significam mais vendas e, portanto, mais lucro. Em bando conversávamos e discutíamos sobre a origem dessa comemoração que agora tornara-se tão estranha. Afinal, que dia é o dia do amigo? Lembrava-se do ano anterior com uma dúvida: mas não há sempre uns dois ou três dias do amigo por ano? Nas mais variadas comunidades virtuais é comum ver aleatórias postagens felicitando os compadres pelo tão especial dia que, afinal, ninguém nem lembrava quando era! Numa rápida pesquisa descobrimos pelo menos três datas para o cada vez mais aclamado dia: uma delas falava do homem chegando à lua, outra sobre uma antiga cruzada pela amizade e ainda uma terceira que dizia de um reconhecimento da ONU sobre a importância da amizade. No Brasil ainda havia uma quarta data "popular" e em todo o globo havia uma confusão com um tal santo namoradeiro. Nos perguntávamos o que significavam a ONU ou a lua numa possível comemoração das nossas amizades. De que jogo falava a aprovação de um dia pelos melhores benefícios de sua lucratividade? Era quase como se dissessem: para que serviria a amizade se não ofertasse rentabilidade?

O tal dia do amigo ainda parece não ter colado, não obstante, nas tentativas pelo aumento do lucro não era incomum percebermos as promoções por aquela figura tão importante da sociedade. Ouviu-se de um comerciante muito didático: "Nem todo mundo tem pai, mãe ou namorado, mas todo mundo tem um amigo. E por que não prestar uma homenagem ao amigo no dia dedicado a ele?" (Diário do Vale, 2011). O que ouvíamos nas entrelinhas dessas palavras era: gaste uns trocados e compre um algo qualquer para o seu amigo. Outro vendedor levantava tristemente uma questão sobre as dificuldades pela consagração do dia, que é o fato de geralmente as pessoas terem mais de um amigo. Dizia: "Acho complicado, pois é raro quem tem um amigo só e você vai eleger aquele seu melhor amigo, mas vai ter que entregar o presente escondido para que os outros não se sintam mal" (idem, ibidem). Parecia-nos que ele torcia para que as amizades se resumissem a uma, talvez duas ou três, para que pudessem efetivamente dar lucro com os presentes regalados. Eram os amigos ganhando outros significados no meio mercantil. 
$* * * *$

Numa ruela avistou-se uma moça jovem e elegante entregando panfletos enquanto passantes deixavam de seguir seus caminhos para ouvir seu discurso empolgado. Chegando mais perto, era possível ouvir as conversas e algumas falas se sobressaíam. Alguém dizia: "meu pozinho do shake acabou, posso pegar o seu contato pra comprar mais?" Por que as pessoas estariam tão interessadas naquilo? Que pó era esse do qual tantos falavam? Com admirável oratória, a jovem discorria sobre a facilidade e praticidade daquela "nutrição" pelo fato de poder levá-la a qualquer lugar - trabalho, academia, faculdade -, e o quanto o pó faria uma contrastante diferença no bem-estar, além de enriquecer o círculo social.

O falatório prosseguia e a moça nos entregou um panfleto. Nossos olhos - que estavam ficando calejados de andanças e questionamentos, mas que não paravam de se surpreender ficaram esbugalhados. O panfleto continha frases como "ser saudável está ao seu alcance", "mais fibras para o seu dia" e, em letras vermelhas: traga um amigo e ganhe desconto na batida de pó. Mesmo que pequeno e comum, o folheto trazia muitos enunciados que envolviam saberes sobre a saúde - e que, não coincidentemente, andavam de mãos dadas com o capital. A venda daquele produto que prometia saúde e vitalidade engendrava discursos sobre a amizade: a empreendedora também os expressava e fazia parte de uma máquina maior de produção de subjetividade capitalística. O discurso dos consumidores - em sua maioria mulheres - trazia, para além de um discurso estético em busca da beleza, "o capitalismo dirigido (...) para a venda ou mercado" (Deleuze, 1992), que como um gás, se espalhava entre vitaminas e fibras por ali, entranhado em enunciados de saúde que repercutiam nas relações daquelas pessoas.

Cada um tinha uma versão da mudança drástica que aquele produto tinha feito em suas vidas. Além de prover um corpo mais leve que caberia naquele biquini novo e uma carteira mais pesada no fim do mês, os produtos tinham trazido algo ainda mais precioso: amigos. Percebia-se enunciados nos quais a saúde, o bem-estar e a amizade viriam em um mesmo pacote que poderia ser consumido. Uma senhora fala sobre sua experiência e diz que perdera doze quilos de pura depressão. Segundo ela, tinha visto numa reportagem que "ter amigos ajudaria contra a depressão e problemas relacionados à depressão e ao tédio e, de acordo com o cardiologista, pessoas depressivas tendem ao sedentarismo e a uma dieta desequilibrada" (Gonçalves, 2011).

Quanto mais elas se alimentavam do pó artificialmente natural, mais ficavam dispostas a vendê-lo. Parecia uma sagaz estratégia biopolítica, através da qual cada um deveria tratar de tornar-se saudável e apto à produção - e, para tanto, cercado de ótimas amizades como se fossem uma caixinha de remédios espetaculares. Um tipo de mercado relacional se engendrava ali, a partir de uma noção estética que modulava cotidianos.

O bando reuniu-se para conversar sobre esta produção de subjetividade. Era um polígono de interesses que reunia a saúde, o dinheiro, as amizades e o trabalho como principal pilar da vida daquelas pessoas. As transações comerciais andavam junto às amizades: o que se fazia ali, 
sem papas na língua, era um esforço intenso para capitalizar os amigos. Assim, os aniversários, as festas típicas e feriados abarcavam significados flutuantes: as fronteiras relacionais tinham se dissolvido por entre transações monetárias, nas quais o pó era assunto central. Os eventos eram uma apelação propagandística onde os produtos estavam sempre à disposição para serem consumidos e também vendidos. Naquele jogo, se perguntavam: quem fazia o publicitário criar? Quem voz impessoal impingia a jovem a vincular saúde, felicidade e amizade? Deleuze havia Ihes ensinado: "o marketing é agora o instrumento de controle social, e forma a raça imprudente de nossos senhores" (Deleuze, 1992, p.224). O bando se perguntava novamente: a amizade poderia escapar desses modos capitalizados?

$* * * *$

Ao transitar pela praça nos deparamos com o palanque de onde um psicólogo, com microfone em mãos, discursava sobre amor e amizade. A fala chamava a atenção: "Os casais mais felizes, com relacionamentos de longo prazo, falavam da presença da amizade no casamento e sobre como amar e fazer amor é uma extensão dessa amizade" (Gonçalves, 2011), contava o especialista à audiência. De acordo com ele, setenta por cento da paixão, do romance e do sexo para os homens decorre da amizade, e a gradação é ainda maior para as mulheres. O psicólogo, segundo ele próprio, estava munido de uma neutralidade científica que advinha dos experimentos empíricos que comprovavam tais resultados. Longe de estar falando a partir de alguma metafísica, os dados trazidos por ele eram factuais, empíricos. Nesse jogo encontrava-se a amizade também a se debater, pois mais do que nunca cientistas se punham na tarefa de comprovar as vantagens de se ter amigos.

$* * * *$

Estávamos constantemente conectados aos cada vez menores gadgets de bolso, aparelhos de subjetivação - das caminhadas pela rua, aos bares da redondeza e mesmo no conforto das camas, com ou sem companhia. As selfies são tiradas aos montes, observávamos ao redor. Atualizações sempre pontuais eram lançadas na rede. Estar com os amigos era motivo para mais uma foto. O passeio, o prato de comida, a maquiagem bem trabalhada, tudo acabava tendo seu correspondente em caracteres virtuais. Ali na praça podia-se ter acesso às dezenas, talvez centenas de feeds borbulhando com frases espertinhas, novos looks, bíceps mais tonificados ou aventuras na cozinha, enfim, uma enxurrada de pedaços editados das vidas propagandeadas. O que fazia ser praticamente necessário registrar cada momento dos dias e convertê-los em bytes a serem compartilhados com o cada vez maior número de amigos? o que convoca a participar de tais rituais tão vaporosamente narcisistas?

"Esta é a moeda de troca nos sites de relacionamento: você expõe um pouco sua intimidade, eu exponho a minha, e assim se criam vínculos" (Portal Educação, 2012), ouvíamos soar pelos smartphones o sábio que em um vídeo muito clicado ia se lançando da tela para nos explicar a lógica por detrás das relações de amizade na rede. Ele enfaticamente nos lembrava 
que não era incomum as empresas contratarem através da web, a ascensão profissional muitas vezes dependia de um bom profile no mundo virtual. Se um futuro emprego estaria ligado à imagem publicizada nas redes de relacionamento, nos parecia não ser à toa que tanto investimento psíquico estivesse direcionado à vida online.

"Estar no Facebook - e em tantas outras redes sociais - se tornou normal, enquanto optar por não participar é esquisito" (Terra, 2012), dizia-nos o sábio do próximo compartilhamento. Ele ia explicando aos transeuntes virtuais que "pessoas sem Facebook são alvo de suspeita de RH e psicólogos" (idem, ibidem), e já não era para nós surpresa ouvir que "psicólogos vêem a existência de perfis na web como indicativo de uma vida social ativa e saudável" (idem, ibidem). O sábio prosseguia nos contando que para a contratação de pessoas em uma empresa, os responsáveis entendem que "a ausência de perfil em algum site de relacionamento pode indicar que o candidato teve sua conta deletada por desrespeitar as regras internas, ou que a pessoa tem informações relevantes a esconder" (idem, ibidem). Saber que o usuário tem uma relação cordial com o antigo chefe através dos sites de relacionamentos é uma das características que algumas empresas procuram num novo candidato. Parecia-nos que não participar dessas modulações virtuais realmente poderia causar estranhamento e, talvez, até ser indício de patologia. Um pop-up pulava interrompendo o discurso do sábio alertando que revistas já haviam vinculado a ausência de participação nas redes sociais com traços de sociopatia - quer saber mais? clique no link: A tal revista associava dois massacres cometidos nos Estados Unidos e Noruega à falta de interação virtual dos dois autores dos crimes. Voltando ao sábio, ele mesmo percebia o exagero da associação daquela interrupção virtual, mas reforçava que era claro que quem se recusa a participar das redes deve "arcar, frequentemente, com a pergunta, de empregadores, psicólogos, amigos: 'por quê?'" (idem, ibidem).

Andando pela orla, a querela do quase ritualístico encontro semanal na pizzaria tomava corpo novamente. De um lado a manutenção do corpo em forma, o cuidado com o sobrepeso, o vigiar quase constante com o conteúdo do prato; de outro a sedução pela ideia daquela deliciosa orgia gastronômica das terças-feiras, afinal de contas, duas pizzas saem pelo preço de uma no dia de marte. Se entregar ao prazer da comida parecia arriscado demais, depois de certa idade não se emagrece tão facilmente, mas o prazer da comensalidade saiu vitorioso, dois por um valia muito a pena.

Os tópicos de conversa não poderiam ser mais díspares, dos meninos e meninas da mesa ao lado às recentes descobertas sobre Foucault ou Benjamin e o novo tópico que ganhava corpo a cada encontro, as amizades e suas capturas pela ciência e pelo capital. Como é possível que por tanto tempo aqueles enunciados pretensiosamente verdadeiros da religião da ciência, ou mesmo as dobras quantificadamente cifradas do deus capital, pudessem ter passado despercebidos, oferecendo um porquê tão simplório aos amigos? Afinal, que bom que 
os amigos fazem bem, mas seria só por isso que temos amigos? Folheando o já conhecido cardápio, voltamos a sempre revisitada discussão pelos sabores. Página por página nos deliciávamos com as belas imagens, meramente ilustrativas, dos pecados da balança, até que a surpresa veio; naquele já diversas vezes manejado álbum o convite matematicamente ilustrado: "Quanto mais amigos, menor o preço para cada um!" Os olhos em bando permitiram atentar para aquela mensagem tantas vezes ignorada, ainda que talvez sempre considerada. Novamente, não era problema o benefício financeiro de se comer com vários amigos, mas era só na carteira que os amigos importavam? E que motivo fazia o criador daquele menu se referir aos amigos apenas em cifras?

$* * * *$

Em nosso caminhar era difícil saber exatamente de onde falávamos. Buscávamos a todo o momento atender aquele convite, e, em nossa curiosidade, caminhávamos. Como falar dos estranhamentos que íamos construindo sem cair no comum da receita outra? Só sabemos que a cada passo dado estranhamos mais e mais as capturas quase automáticas que a todo o momento se apresentam aos amigos. Perguntamo-nos sobre a suposta neutralidade científica lembrando da célebre lição foucaultiana: toda a construção de conhecimento é invenção, é ato político. Seria válido, então, separar o pessoal do impessoal acreditando ser possível higienizar um lugar descolado de afetos? E quando a aposta no afeto é justamente o indispensável para lutar contra a tirania dos enunciados de verdade?

Caminhando e vendo os filhotes na feirinha de adoção, a questão da amizade surgia novamente. Poderia um animal não-humano ser considerado um amigo? Seguindo as falas dos sábios, lembrávamos que as relações de amizade melhoram a saúde. Em alto e bom som se ouviam, através das portas das clínicas veterinárias e pet shops: Pesquisas também mostram que o carinho em bichos de estimação aumenta a produção de ocitocina (Prevention, 2013). Se um animal não-humano pode melhorar a saúde, ele poderia ser considerado um amigo. Então é a partir do benefício da saúde que o presente faz definir uma amizade? A obviedade daqueles enunciados ainda surpreendia, pois saídos das bocas de uns poucos pareciam se dissolver nas falas dos que ali passavam. Por que os sábios se importam tanto com a nossa saúde?

Sentando em um café, as sempre calorosas discussões continuavam. Lembrou-se de uma referência ouvida certa vez, sobre a antrozoologia, uma nova área de estudos que se debruça sobre as relações entre animais humanos e animais não-humanos. Na fala da bemintencionada sábia que discursava aos transeuntes ouviu-se que "você leva um animal para um hospital o ambiente muda, as pessoas ficam mais comunicativas, e se sentem mais relaxadas, mas antes que isso seja científico é necessário pesquisa, é necessário estudo, pois para convencer os governos a investir nesse tipo de programa, que sabemos ser ótimo, precisamos de evidência [científica], precisamos provar que funciona" (tradução nossa², AARF, 2013).

$2 \quad$ "you take an animal in a nursing home and it changes the atmosphere, and people will become more communicative by feel more relaxed. But for it to be a scientific undestanding of that, we need research, we need to really 
Lembrávamo-nos daquele dia com um novo entendimento, percebendo a utilidade, cientificamente comprovada e quantificadamente cifrada, como o ponto sensível para a mudança de um paradigma.

Através dos ensinamentos de Benjamin que, sob a égide da religião do capitalismo, "puramente cultual, [onde] o utilitarismo obtém sua coloração religiosa" (2013, p.21), íamos entendendo que primeiro é necessário aduzir a utilidade de algo ao capital, - onde as descargas de ocitocina parecem realizar um excelente trabalho - e em seguida monetizar seu valor.

Voltando aos bichinhos que ainda latiam ali perto, pensávamos em como nos parece normal medir a importância de um não-humano pelo seu potencial terapêutico, mas e quando a ciência nos convida a entender a amizade entre humanos da mesma forma, quantificando seu valor nas descargas de ocitocina e benefícios dos mais diversos? Parecia-nos que, nos braços do capital, todos somos sempre convocados a ser objetos, a carregar cifrões marcados na pele.

$* * * *$

Não era mais possível supor uma construção sem caminhada. Mesmo que mínimo, a construção supõe o andar. Como é possível, na surpresa da constatação dos passos inadvertidamente dados, perceber a criação de relações que podem ter explicações tão simplórias? Como é possível, quando a surpresa da transformação desses encontros que inventam amizades é tão estranha, que eles sejam capturados tão diminutamente pelo discurso que aprisiona e higieniza em vetores unificantes de quantificações químico-moleculares monetizadas o construir de amizades?

De volta à praça, as perguntas continuavam sem respostas e ainda pipocavam em nossas cabeças. O que os jogos do presente faziam das relações de amizade? O que levava a amizade a ser objeto de ditos de verdade? Seria ela um dispositivo no jogo biopolítico? Lembrando de nossas andanças, ainda debatíamos se saúde, alegria, amizades, produtos e dinheiro se conectam. A serviço de que estariam tais amizades? Que mundo essa união ajudava a construir? Que mundo nós ajudávamos a construir?

O bando não pararia de andar: seguia desacreditando dos inícios e dos fins. Estupefato, assustado, inquieto, insatisfeito: a vinculação entre a amizade, a saúde e o capital, cada vez mais presente, ainda era estranha. Ainda e sempre no meio, a pergunta seguia nos acompanhando na andança: afinal, o que aquele mundo fazia das amizades?

study it. Because if we gonna convince governments to put money into funding these sort of programs that we all now are wonderful, we need evidence. We need to prove that it works [...]" (AARF, 2013) 


\section{References}

ASSOCIAÇÃO BRASILEIRA DE PSIQUIATRIA. Amizade combate a depressão. Disponível em: <http://abp.org.br/2011/medicos/clippingsis/exibClipping/?clipping=3417>. Acesso em: 26 Julho 2015.

AUSTRALIAN ANTHROZOOLOGY RESEARCH FOUNDATION. Why do we need anthrozoology research? Disponível em: <https://www.youtube.com/watch?v=e4LVS2ZTSVw>. Acesso em: 17 Julho 2015.

BENJAMIN, W. O capitalismo como religião. São Paulo: Boitempo Editorial, 2013.

BENJAMIN, W. Infância em Berlim por volta de 1900. Tiergarten. In: Obras escolhidas, vol. II. São Paulo: Brasiliense, 1987.

CASTRO, E. Vocabulário de Foucault - um percurso pelos seus temas, conceitos e autores. Belo Horizonte: Autêntica Editora, 2009.

CERTEAU, M. D. A invenção do cotidiano: 1. Artes de fazer. Petrópolis: Editora Vozes, 2012.

DELEUZE, G. Conversações, 1972-1990. São Paulo, Ed. 34, 1992.

DELEUZE, G.; GUATTARI, F. Introdução: Rizoma. In: Mil Platôs: capitalismo e esquizofrenia 2, vol. 1. São Paulo: Ed. 34, 1995.

DIÁRIO DO VALE. Comércio tenta esquentar vendas com Dia do Amigo. Disponível em: <http://diariodovale.uol.com.br/noticias/4,43528,Comercio-tenta-esquentarvendas-com-Dia-doAmigo.html\#ixzz1ShE50UrY>. Acesso em: 20 Julho 2011.

FOUCAULT, M. A hermenêutica do sujeito. São Paulo: Martins Fontes, 2006.

FOUCAULT, M. As palavras e as coisas: uma arqueologia das ciências humanas. São Paulo: Martins Fontes, 2000.

FOUCAULT, M. Michel Foucault entrevistado por Hubert L. Dreyfus e Paul Rabinow. In: DREYFUS, H.; RABINOW, P. Michel Foucault: uma trajetória filosófica (para além do estruturalismo e da hermenêutica). Rio de Janeiro: Forense Universitária, 1995a.

FOUCAULT, M. Sobre a genealogia da ética: uma revisão do trabalho. In: DREYFUS, H.; RABINOW, P. Michel Foucault: uma trajetória filosófica (para além do estruturalismo e da hermenêutica). Rio de Janeiro: Forense Universitária, 1995b.

FOUCAULT, M. História da sexualidade 1: a vontade de saber. Rio de Janeiro: Edições Graal, 1988.

FOUCAULT, M.; DELEUZE, G. Os intelectuais e o poder. In: FOUCAULT, M. Microfísica do poder. Rio de Janeiro: Graal Editora, 1979.

GONÇALVES, L. Dia do amigo: oito benefícios que a amizade traz para sua vida. Disponível em: <http://msn.minhavida.com.br/conteudo/13143-Dia-do-amigo-oito-beneficios-que-a-amizade-traz-parasua-vida.htm?ordem=8\#gal >. Acesso em: 18 Julho 2011 .

GROS, F. Caminhar: uma filosofia. São Paulo: É Realizações Editora, 2010.

GROS, F. Situação do curso. In: FOUCAULT, M. A hermenêutica do sujeito. São Paulo: Martins Fontes, 2006 GUATTARI, F.; ROLNIK, S. Micropolítica: cartografias do desejo. Petrópolis: Editora Vozes, 1996.

JETTEN, J.; HASLAM, C.; HASLAM, A.; BRANSCOMBRE, N. O poder terapêutico dos grupos. In: Revista Mente e Cérebro. Ano XVII. Número 208. Maio de 2010.

JOBIM, T. Wave. In: Wave: A\&M Records, 1967. 
MASSEY, D. Pelo espaço: uma nova política da espacialidade. Rio de Janeiro: BertrandBrasil, 2008.

O GLOBO. Conheça a Path, nova rede social na qual não se pode ter mais de 50 amigos. Disponível em: <http://oglobo.globo.com/tecnologia/mat/2010/11/19/conhecapath-nova-rede-social-na-qual-nao-sepode-ter-mais-de-50-amigos-923054482.asp>. Acesso em: 19 Novembro 2010.

PORTAL EDUCAÇÃO. A importância da amizade. Disponível em: <http://www.portaleducacao.com.br/educacao/artigos/20919/a-importancia-da-amizade>. Acesso em: 12 Julho 2015.

PREVENTION. How your pet can heal you. Disponível em: <http://www.prevention.com/health/healthyliving/healing-power-pets>. Acesso em: 27 Julho 2015.

RABINOW, P.; ROSE, N. O conceito de biopoder hoje. In: Revista Política \& Trabalho: Revista de Ciências Sociais, número 24. p. 27-57. ISSN 0104-8015. 2006.

SUPER INTERESSANTE. A amizade é uma das coisas mais importantes das nossas vidas. Disponível em: <http://super.abril.com.br/comportamento/a-amizade-e-uma-das-coisas-mais-importantes-de-nossasvidas>. Acesso em: 27 Julho 2015.

TERRA. Pessoas sem Facebook são alvo de suspeitas de $R H$ e psicólogos. Disponível em: <http://tecnologia.terra.com.br/internet/pessoas-sem-facebook-sao-alvo-de-suspeitas-de-rh-epsicologos,d728201fd70ea310VgnCLD200000bbcceb0aRCRD.html>. Acesso em: 20 Julho 2015.

WORLD HEALTH ORGANIZATION. Depression. Disponível em: <http://www.who.int/mediacentre/factsheets/fs369/en/>. Acesso em: 26 Julho 2015.

Recebido em janeiro de 2016

Aprovado para publicação em janeiro de 2018

\section{Caio Augusto Ramos de Castilho}

Graduando de Psicologia - Universidade Federal Fluminense -UFF, Brasil, caiodecastilho@gmail.com

\section{Clara Sym Cardoso de Souza Costa}

Graduanda de Psicologia - Universidade Federal Fluminense - UFF, Brasil, clarasym@hotmail.com

\section{Ana Carolina Dias Ramos}

Graduanda de Psicologia - Universidade Federal Fluminense - UFF, Brasil, anacarolina.diasramos@hotmail.com

Júlia Paim Mas

Graduanda de Psicologia - Universidade Federal Fluminense - UFF, Brasil, juliapaim@id.uff.br.com

Vinícius Jerônimo da Silva

Graduando de Psicologia - Universidade Federal Fluminense - UFF, Brasil, viniciusjeronimo@gmail.com

Diogo de Lima Muniz Barroso

Graduando de Psicologia - Universidade Federal Fluminense - UFF, Brasil, d-ogo@hotmail.com

Marcelle da Silva Freitas

Graduanda de Psicologia - Universidade Federal Fluminense - UFF, Brasil, freitas.celle@gmail.com

Rafael Pires Pinto

Graduando de Psicologia - Universidade Federal Fluminense - UFF, Brasil, rafaelpirespinto@gmail.com

Tali Firer

Graduanda de Psicologia - Universidade Federal Fluminense - UFF, Brasil, talifirer@gmail.com

\section{Júlia Virginio Câmara}

Graduanda de Psicologia - Universidade Federal Fluminense - UFF, Brasil, julia.vcamara@gmail.com

\section{Jiulia Caliman Muylaert de Menezes}

Graduanda de Psicologia - Universidade Federal Fluminense - UFF, Brasil, jiulia.c@gmail.com

Danichi Hausen Mizoguchi

Professor do Programa de Pós-Graduação em Psicologia - Universidade Federal Fluminense - UFF, Brasil, danichihm@hotmail.com 